\title{
Evaluation of Jakabaring Lake Area Management as a Potential Sport Tourism Destination in Jakabaring Sport City, Palembang City
}

\author{
Wisanggeni Agus P. ${ }^{1}$, Muhammad Iqbal D. ${ }^{2}$, Daniel Sihombing ${ }^{3}$ \\ ${ }^{1,2,3,}$ Politeknik Pariwisata Palembang \\ *Corresponding Author.Email: muidjohan@poltekpar-palembang.ac.id
}

\begin{abstract}
The city of Palembang is very potential as a tourist destination for Sport Tourism because it has Jakabaring Sport City which since 2005 has a vision of the development area of Integrated Sports Complex. This study uses the CIPP method Stufflebeam's CIPP Model (2003), this model is suitable for knowing the progress of the tourism destination sector. By focusing on evaluating aspects of context, input, process, and product, the CIPP model is consistent with the definition of program evaluation conducted by PT. Jakabaring Sport City in the Jakabaring. This study uses a mixed-method, where the researcher is the key instrument and the data collection technique is carried out by combining and analyzing the data findings so that more comprehensive, valid, reliable, and objective data will be obtained. The results obtained in this study refer to the evaluated aspects, namely in the context aspect which is described with the basic indicators of program implementation carried out by PT. Jakabaring Sport City in the Jakabaring Lake area then analyzes the program needs and what obstacles are faced. From the input aspect, analyze the existing condition of employees, the duties of each section, supporting facilities, and infrastructure, tourism facilities consisting of basic, complementary, and supporting facilities, and the budget used. Meanwhile, from the process aspect, it focuses on tourist activities in the Jakabaring lake area and the assessment of employee services. Then the last is to present data related to the level of satisfaction of tourists visiting the Jakabaring lake area.
\end{abstract}

Keywords: Sport Tourism, Evaluation, Destination

\section{INTRODUCTION}

Today's tourism is believed to be one way to utilize and develop a potential area, by generating economic growth through economic diversification and helping reduce poverty, and creating reciprocal relationships with other products and service providers, which we later know as tourism multipliers. effects. Tourism is not only limited to the benefits mentioned above but can also grow and increase the introduction of culture and a sense of love for the homeland, and pride as an entity of a culture and nation. From the point of view of local authorities (Pemda), the tourism sector can also contribute to the receipt of Regional Original Income collected from taxes related to the 13 types of tourism businesses in Law No. 10 of
2009 concerning Tourism. the economy around the tourist area and support its activities so that it can increase people's income and of course for investors as managers of tourist destinations. The utilization and development of tourism in question should be based on the potential of the region or destination is, this is supported by the opinion of Suarka (2010) which states that the development of a tourism destination must be designed based on the potential of tourist attractions owned by each destination. can later support its development. From the preresearch data, the development that is considered the most potential for the city of Palembang as the capital of South Sumatra Province is Sport Tourism because, in the field of sport tourism, tourist attractions can be in the form of sports activities, 
main stadiums, sports venues, sports museums, and everything related to sports., which can attract tourists to come to a destination. since 2015 the focus of tourism development on districts/cities in South Sumatra Province based on the 2013-2014 RPJMD stipulates that Jakabaring Sport City will focus on developing sports tourism (namely organizing national and international sports events). The Provincial Government of South Sumatra developed an initiative program for the Jakabaring Sports Center Masterplan as a revision of the Sports and Settlement Center Masterplan. This step adds sports facilities and an athlete's home which is now used as a sports tourism destination so that this area is expected to be a choice for tourist destinations, especially in the city of Palembang. As an icon of Sport Tourism, Jakabaring Sport City does have large funds to support the development of Sport Tourism in Palembang, this is shown by data on international and national sports events held at Jakabaring Sport City from year to year, as follows:

Table 1 International and National Sports Events Held at Jakabaring Sport City

\begin{tabular}{|c|c|c|c|c|}
\hline No & Event & Year & Level & Venue JSC \\
\hline 1 & $\begin{array}{l}\text { Beach Volley Asia - } \\
\text { Pacific Governor } \\
\text { Cup }\end{array}$ & 2012 & $\begin{array}{l}\text { Asia - } \\
\text { Pacific }\end{array}$ & $\begin{array}{l}\text { Kompleks } \\
\text { JSC }\end{array}$ \\
\hline 2 & $\begin{array}{l}\text { Tournament } 36^{\text {th }} \\
\text { South East Asia Age } \\
\text { Group Swimming } \\
\text { Championship }\end{array}$ & 2012 & Asia & Volly Beach \\
\hline 3 & $\begin{array}{l}\text { Tournament The } \\
\text { South Sumatera } \\
\text { Governor Cup } \\
\text { Aerobic Gymnastic }\end{array}$ & 2012 & Asia & $\begin{array}{l}\text { Jakabaring } \\
\text { Lake }\end{array}$ \\
\hline 4 & $\begin{array}{l}\text { Tournament Water } \\
\text { Ski \& Wakeboard } \\
\text { World Cup }\end{array}$ & 2012 & World & $\begin{array}{l}\text { Jakabaring } \\
\text { Lake }\end{array}$ \\
\hline 5 & $\begin{array}{l}\text { South Sumatera } \\
\text { Premium ASTC/ITU } \\
\text { Triathlon - Dualthon } \\
\text { Championship }\end{array}$ & 2013 & World & $\begin{array}{l}\text { Kompleks } \\
\text { JSC }\end{array}$ \\
\hline 6 & $\begin{array}{l}3^{\text {rd }} \text { South Sumatera } \\
\text { Governor Cup Asia } \\
\text { Pasific Beach } \\
\text { Volleyball Tour }\end{array}$ & 2013 & $\begin{array}{l}\text { Asia- } \\
\text { Pacific }\end{array}$ & $\begin{array}{l}\text { Kompleks } \\
\text { JSC }\end{array}$ \\
\hline 7 & $\begin{array}{l}\text { World Cup } \\
\text { Tournament Water } \\
\text { Ski \& Wakeboard } \\
\text { Championship }\end{array}$ & 2013 & World & $\begin{array}{l}\text { Jakabaring } \\
\text { Lake }\end{array}$ \\
\hline 8 & $\begin{array}{l}\text { South East Asia } \\
\text { Canoe Championship }\end{array}$ & 2013 & Asean & $\begin{array}{l}\text { Jakabaring } \\
\text { Lake }\end{array}$ \\
\hline 9 & $\begin{array}{l}\text { Kejurnas Dayung } \\
\text { Junior U-15 }\end{array}$ & 2013 & National & $\begin{array}{l}\text { Jakabaring } \\
\text { Lake }\end{array}$ \\
\hline 10 & $\begin{array}{l}3^{\text {rd }} \text { Islamic Solidarity } \\
\text { Games }\end{array}$ & 2013 & World & $\begin{array}{l}\text { Kompleks } \\
\text { JSC }\end{array}$ \\
\hline 11 & $\begin{array}{l}\text { ASIAN University } \\
\text { Games }\end{array}$ & 2014 & Asean & $\begin{array}{l}\text { Kompleks } \\
\text { JSC }\end{array}$ \\
\hline
\end{tabular}

Source: PT. Jakabaring Sport City and KONI of South Sumatra Province (2021).

Most international level sports activities were held in 2012 until the 18th Asian Games was held in 2018, and the most used venue was Jakabaring Lake, so the maintenance of the Jakabaring lake area should be a priority for the manager, in this case, PT. Jakabaring Sport City. utilization of sports venues after mega sports events is still homework for local managers, so extra efforts are needed for managers in this case PT. Jakabaring Sport City to maximize all existing potential, especially in spots that are not only intended for sporting events but also for other recreational activities for non-athlete visitors, one of which is the Jakabaring Lake venue, so that income can continue to be obtained so that management can run continuously and sustainable. Based on the data described on this background, the research team of the Convention and Event Management Study Program at the Palembang Tourism Polytechnic wanted to see further how the management of Jakabaring Lake in the Jabaring Sports City Complex, by submitting the research title "Evaluation of Jakabaring Lake Area Management as Potential Sports Tourism-Based Tourist Destinations in Jakabaring Sport City, Palembang City".

\section{LITERATURE RIVIEW}

\subsection{Management}

Management is one word that is very often used in everyday life. Management itself comes from the word to manage which means to manage or manage. According to Sudjana (2000), "management or management is the ability and special skills to carry out an activity either with other people or through other people in achieving organizational goals". Musselman in Wiludjeng (2007) explains that "management is the process of planning, organizing, directing, and controlling the activities of an enterprise to achieve specific objectives".

\subsection{Evaluation}

Worthen and Sander in Arikunto (2009) "evaluation is an activity to find something valuable about something, also includes seeking useful information in assessing the existence of a program, production, procedure, and alternative strategies 
proposed to achieve predetermined goals". The word evaluation itself comes from the English absorption evaluation which means assessment or assessment. In carrying out the evaluation, seven elements must be carried out, namely: a) focusing the evaluation, b) designing the evaluation, c) collecting information, d) analyzing and interpreting d) reporting information, e) Managing evaluation, and f) Evaluating evaluation. Widoyoko (2011)

\subsubsection{Context Evaluation}

Context evaluation to serve planning decision". Konteks evaluasi ini membantu merencanakan keputusan, menentukan kebutuhan yang akan dicapai oleh program, dan merumuskan tujuan program. Context evaluation is the basis of evaluation which aims to provide rationale in determining goals. Sax in Eko Putro Widoyoko (2009: 181) defines context evaluation as follows: "the delineation and specification of the project's environment, it's unmet, the population and sample individual to be served, and the project objectives. Context evaluation provides a rationale for justifying a particular type of program intervention". According to Tayibnapis (2008: 14) "context evaluation to serve planning decision". This evaluation context helps plan decisions, determine the needs to be achieved by the program, and formulate program objectives.

\subsubsection{Evaluation of Inputs}

An evaluation that aims to provide information to determine how to use the available resources in achieving program objectives. According to Stufflebeam in Eko Putro Widoyoko (2009), "questions related to input lead to solving problems that encourage the implementation of the program in question. The input evaluation components include:

1. Human resources.

2. Supporting infrastructure and facilities.

3. Fund or budget.

4. Various procedures and rules are required.

\subsubsection{Process Evaluation}

This evaluation is designed and applied in implementation practice, so the activity is called process evaluation. With this process evaluation, the book can review the plans that have been made and check important aspects that must be monitored by us. Worthen \& Sanders in Eko Putro Widoyoko (2009) emphasizes that process evaluation has three objectives "(1) to detect or predict in procedural design or its implementation during the implementation stage, (2) to provide information for programmed decisions, (3) to maintain a record of the procedure as it occurs".

\subsubsection{Product Evaluation}

This evaluation aims to measure, interpret and assess program achievements. Usually, this evaluation is carried out by analyzing from various perspectives the activities that have been carried out. According to Sax in Eko Putro Widoyoko's book (2009), the function of product or outcome evaluation is "to allow the project director (or teacher) to make decisions regarding continuation, termination, or modification of the program". When viewed from the organization of sports events carried out in the Jakabaring Sports City area, Karo, in his research on the Jakabaring Wonderful Run event, found that 86.6 percent of event participants were often people who had participated in other events before. This study found that the indicators of action, which included communication and response of the organizing committee, had a significant impact on the evaluation of the event's organization (Karo Karo \& Rahman, 2020).

\section{RESEARCH METHODS}

By using the mixing method or a combination of qualitative and quantitative, where the researcher is placed as the key instrument and data collection techniques are carried out by combining and analyzing the data findings. the writing team did in analyzing qualitative descriptive data were:

a. Collecting data, carried out both observation, interviews, and documentation.

b. Identifying problems, which are related to the management of Jakabaring Lake.

c. Analyzing, which is analyzing based on data that has been obtained previously

d. Provide conclusions, suggestions, and recommendations regarding the management of Jakabaring Lake.

The respondents of this study were the managers of the Jakabaring Lake area and parties involved in organizing activities at Jakabaring 
Lake. The collection techniques we will use are: a) interviews, b) observation, c) questionnaires, d) documentation, and e) literature study.

In this case, the author uses the results of observations and interviews as primary data. Some of the secondary we will get from documentation activities as well as literature studies and blueprints for planning the development of the JSC area. The research location that the research team carried out was in Jakabaring Lake, Silaberanti, Seberang Ulu I, Jakabaring Sport City, Palembang, Palembang City, South Sumatra, 30267.

\section{RESEARCH RESULT}

As explained in the previous chapter, the evaluation used in this study is the CIPP concept which includes 4 (four) things, namely the context as a description and specification of the program environment, unmet needs, and population characteristics of the individual program. The results of the context evaluation are to provide several alternative decisions, namely: the settings to be applied, the goals and objectives to be achieved.

Input evaluation provides information about managing decisions, determining available sources, alternatives taken, and what strategies to achieve goals. The components in the input evaluation are human resources, supporting facilities and equipment, budget, and required procedures or rules.

Process, this evaluation is useful for detecting program design during the implementation phase, providing information on program decisions, and as an archive of processes that have occurred. Process evaluation provides benefits to determine if program implementation is in accordance with the plan or not and what things need to be improved. So, process evaluation is the implementation of real activities in the field.

Product evaluation is an assessment of the success of an activity that has been planned with predetermined goals. The results of the evaluation aim to determine whether the program will be continued or not.

\subsection{Context Evaluation}

\subsubsection{Background of the Program Implemented}

Based on the results of field observations, it was found that PT. Jakabaring Sport City (PT JSC) was founded based on the vision of the Governor of South Sumatra Province to create a modern sports area of international standard with "smart" and "green" characters. The development of the Jakabaring Sport City (JSC) area is carried out in stages and continuously, starting in 2001 and continuing with the implementation of the PON in 2004 and continuing to be developed until the SEA Games in 2011, and until the Asian Games in 2018.

Initially, the management of the Jakabaring Sport City area was under and the responsibility of the Regional Asset Management Agency (BPKAD), a South Sumatra Provincial Government agency. In its development, it was deemed necessary to improve the effectiveness of its management, so the South Sumatra Provincial government took the initiative to form a Regional Owned Enterprise that was independent and could manage the Jakabaring Sport City area professionally.

\subsubsection{Program needs analysis}

Based on the results of observations and interviews conducted by the research team, it can be concluded that the program needs based on the mission set by PT. Jakabaring Sport City at Jakabaring Lake are as follows:

1. Promotion and building brand awareness as well as support from all relevant stakeholders in organizing local, national, and international sports and sports events.

2. It is possible to maintain and utilize the available venues to be used not only for sporting activities but also to organize national and international exhibitions.

3. Policies and management patterns that are more comprehensive and mutually beneficial as well as the ease and access of providing facilities to support the culinary tourism program by making domestic and international culinary counters based on hygiene and sanitation according to international standards.

4. Facilities and facilities, especially those related to safety and security, in supporting efforts to provide family recreation facilities.

5. Policies and management patterns that are more comprehensive and mutually 
beneficial as well as convenience and access to provide a place for MSMEs to improve the local economy.

6. The required facilities and infrastructure as well as the upgrading of related employees to support the digitization program of facilities and utilities that are energy efficient and conduct waste management in an environmentally friendly manner.

\subsubsection{Program Implementation Objectives}

Based on the results of observations and interviews conducted by the research team, it can be concluded that the objectives of implementing the program are based on the mission that has been set by PT. Jakabaring Sport City at Jakabaring Lake are as follows:

1. Develop promotional activities and all related matters and are available to do to build brand awareness and support from all stakeholders in the implementation of sports and sporting events on a local, national and international scale.

2. Optimization of maintenance activities and utilization of available venues so that it is possible to use them not only for sporting activities but also to organize national and international exhibitions.

3. Aligning policy governance and management patterns that are more comprehensive and mutually beneficial plus providing convenience and access to the provision of facilities that support facilities for culinary tourism programs by making domestic and international culinary counters, based on hygiene and sanitation according to international standards.

4. Establish high standards for facilities and facilities, especially those related to safety and security in supporting efforts to provide family recreational facilities.

5. Align all policies and management patterns that are more comprehensive and provide convenience and access to the provision of facilities that support the optimization of development for MSMEs to improve the local economy.

6. Upgrading employees in the form of HR development training as well as the necessary facilities and infrastructure related to supporting the application of digitizing energy-efficient facilities and utilities and initiating environmentally friendly waste management actions.lingkungan.

\subsubsection{Obstacles Ecountered}

In general, there are several obstacles faced by the manager of Jakabaring Sport City. These include:

a. Very high maintenance and maintenance costs. The results of the interview with the manager stated that the maintenance and care of the Jakabaring area are indeed very high. Most of the costs are sucked in for this. Not to mention added with other costs such as employee salaries.

b. The coverage area is very wide which makes it difficult to maintain and supervise. The manager mentions "What a great maintenance paddle venue

c. The number of events held in the Jakabaring Sport City area that did not contribute financially. The manager mentioned that sometimes there are events that do not contribute financially to the manager, or even if they do, the amount is very small. These events usually come from the government or from activities related to officials.

d. There are quite a number of areas that are not financially profitable. In general, Jakabaring Sport City has an area/venue that generates income. However, on the other hand, there are also venues that do not generate income due to several factors, including the venue being a sports venue that is not well-known in the eyes of the public. The second is a venue with an infrequent level of visits and usage, which of course will have a huge impact on revenue. Jakabaring Lake itself is included in the category of use outside the building/venue of Jakabaring Sport City Palembang. The fare is Rp. 7,500,000,- for the first 6 hours and Rp.1,500,000 for the next hour. 


\subsection{Input Evaluation}

\subsubsection{Existing Conditions of Employee}

a. Organizational Structure of PT Jakabaring Sport City (JSC), The organizational structure is how work is formally divided, grouped, and coordinated. Below is the structure of Jakabaring Sport City Palembang:

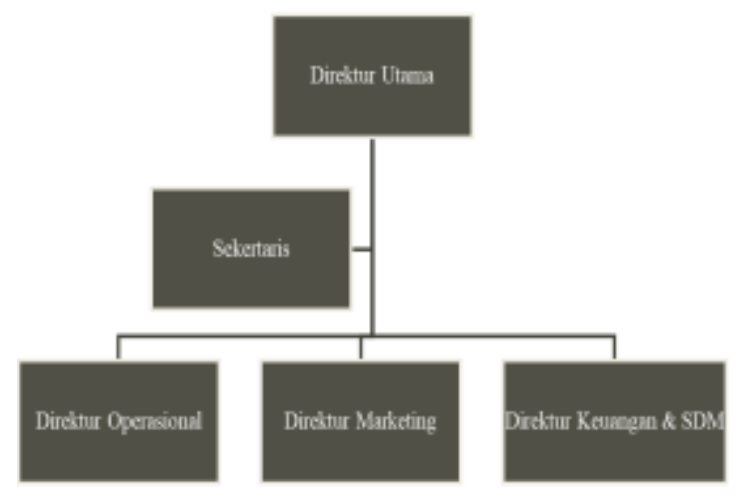

Figure 2 Organizational Structure

Source: PT JSC Management (2021)

\subsubsection{Task for each Section}

There are several duties of leaders and their subordinates as follows:

1. President Director, Leads the company by assisting and supervising his subordinates in carrying out their respective duties.

2. Secretary, as an intermediary for external parties who wish to agree with the president director.

3. Director of Operations, makes strategies to be taken for the progress of the company.

4. Marketing Director, directs and supervises all marketing activities.

5. Director of Finance and HR, as the manager of finance and human resources.

\subsubsection{Supporting infrastructure and facilities}

There are several duties of leaders and their subordinates as follows:

1. President Director, Leads the company by assisting and supervising his subordinates in carrying out their respective duties.

2. Secretary, as an intermediary for external parties who wish to agree with the president director.
3. Director of Operations, makes strategies to be taken for the progress of the company.

4. Marketing Director, directs and supervises all marketing activities.

5. Director of Finance and HR, as the manager of finance and human resources.

\subsubsection{Tourism Facilities}

1. Basic Tourism Facilities

2. Tourism Equipment Facilities

3. Tourism Supporting Facilities

\subsubsection{Funds or Budget}

The results of the interview with Jakabaring Sport City management stated that the funds and budget received were not sufficient to manage the entire complex area. Then the use of the area is divided into areas that produce and areas that do not produce. This policy is expected to provide a solution to the shortage of operational costs.

From this table, it can be seen that the levy rates charged to users of the Jakabaring Sport City area are very cheap, especially those that are adjacent to and related to Jakabaring Lake. This strengthens the information that the author's team got from the manager where the manager stated that the levy obtained was not in accordance with the required maintenance budget. To boost revenue, one of the things implemented by the manager is to implement a new system of automatic doors or auto gates. Quoted by garta.com, the manager said that income was higher than before, namely Rp. 43 million on Saturday and 75 million on Sunday.

\subsection{Process Evaluation}

\subsubsection{Tourist Activities in Jakabaring Lake}

Some of the activities that can be developed and carried out by tourists in the area include sightseeing, water sports such as canoeing, dragon boats, then other activities such as jogging, leisurely walks, and fun activities such as banana boating. But for now, the activities carried out are only activities around the lake such as children's games and enjoying culinary beside the lake. In addition, several things related to the involvement of parties related to the activities that occurred at Jakabaring Lake. The first is management. In this case, it is dominantly carried out by the security team in charge of going around the Jakabaring Lake 
area to carry out security. In addition, the management is not much involved. The second is from traders and game equipment tenants. Their activities are peddling merchandise such as snacks, mineral water and renting game equipment such as bicycles and several other things.

\subsubsection{Result of PT.JSC's employee service assessment}

The total respondents were 83 visitors. In general, visitors give a fairly positive impression of the services provided by employees.

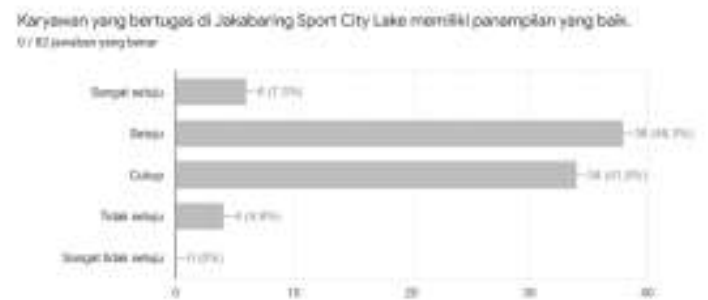

Figure 3 Respondents' preferences on the appearance of PT. Jakabaring Sport City employees Source: Processed by the research team (2021)

From the survey results, it can be seen that the respondents dominantly stated that the employees on duty at Jakabaring Lake had a good appearance. As many as 46.3 percent of respondents agree with this statement.

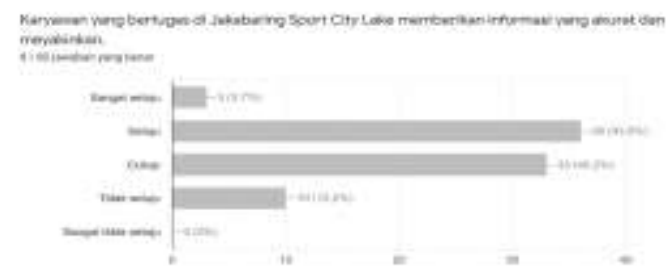

Figure 4 Respondents' preferences for providing information by employees of PT. Jakabaring Sport City.

Source: Processed by the research team (2021)

Meanwhile, in terms of the accuracy of the information, as many as 43.9 percent of respondents answered agree and $40.2 \%$ answered enough. Only 3.7 percent answered strongly agree while others answered disagree.

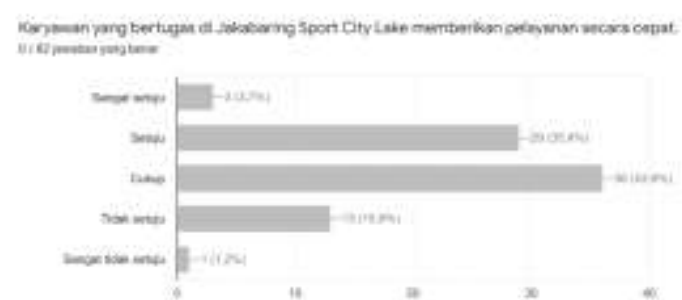

Figure 5 Respondents' preferences on the speed of service delivery by employees of PT. Jakabaring Sport City.

Source: Processed by the research team (2021)

Respondents stated that employees on duty at Jakabaring Lake have provided fast service. A total of 35.4 percent of respondents agreed with this statement. 43.9 percent answered quite related to service.

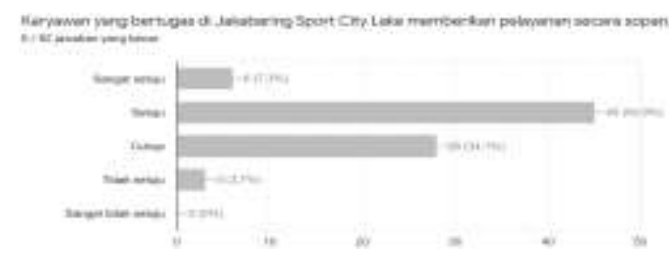

Figure 6 Respondent's preference for hospitality by employees of PT. Jakabaring Sport City

Source: Processed by the research team (2021)

A total of 54.9 percent of respondents said that the employees on duty at Jakabaring Lake provide courteous service.

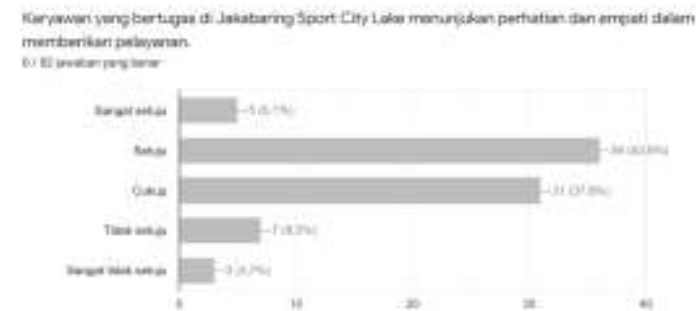

Figure 7 Respondents' preferences for providing information by employees of PT. Jakabaring Sport City

Source: Processed by the research team (2021)

When viewed from the results above, the majority of respondents agree that employees show concern and empathy. Only 3.7 percent strongly disagree.

\subsection{Product Evaluation \\ 4.4.1 Tourist Satisfaction Level}

The following is a processed questionnaire regarding the level of tourist satisfaction with Jakabaring Lake. Same as a questionnaire about employee services. In general, the level of 
satisfaction is at the positive level. The following is an explanation of the results of the questionnaire.

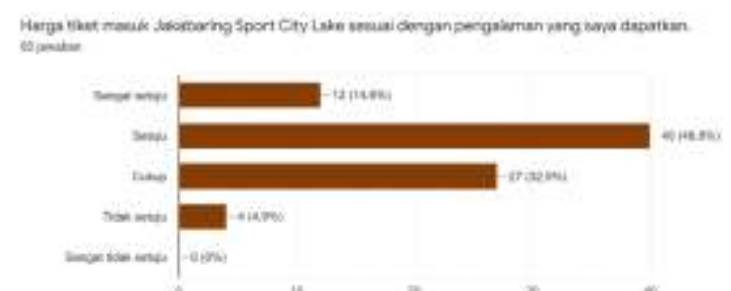

Figure 8 Respondents' preference for ticket prices for the experience they had at Jakabaring Lake Source: Processed by the research team (2021)

The price of admission to the Jakabaring area is indeed not expensive when compared to the experience gained. It is proven that none of the respondents stated that they strongly disagreed with the suitability of the experience gained.

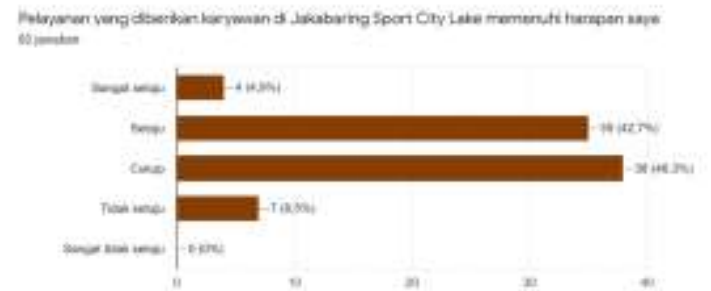

Figure 9 Respondents' expectation preferences for services provided by employees at Jakabaring Lake Source: Processed by the research team (2021)

From the results of the survey above, it can be seen that the respondents stated that the service of the employees on duty at Jakabaring Lake had met their expectations. A total of 42.7 percent of respondents agreed with this statement.

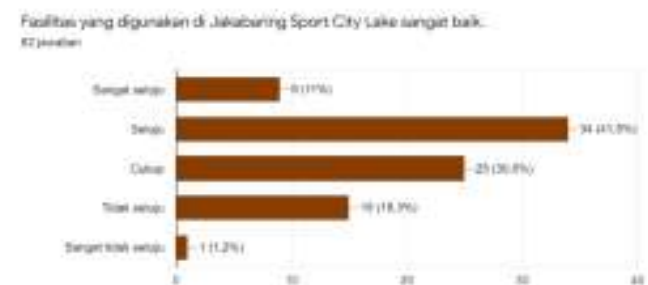

Figure 10 Respondents' preferences for services provided by employees at Jakabaring Lake Source: Processed by the research team (2021)

Respondents from the survey above stated that the Jakabaring Lake facilities were quite good. A total of 30.5 percent of respondents agree with this statement.

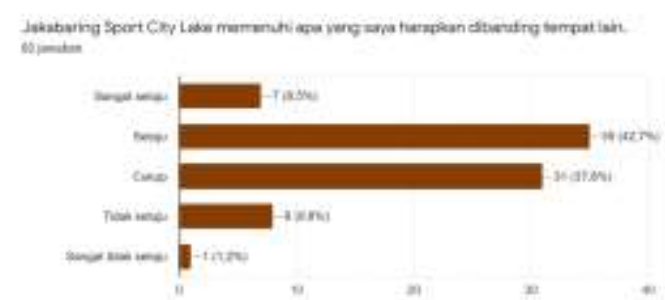

Figure 11 Respondents' expectation preferences for Jakabaring Lake Destinations

Source: Processed by the research team (2021)

As many as 42.7 percent of respondents stated that Jakabaring Sport Lake met what I expected compared to other places. Meanwhile, 37.8 percent of those who voted were sufficient.

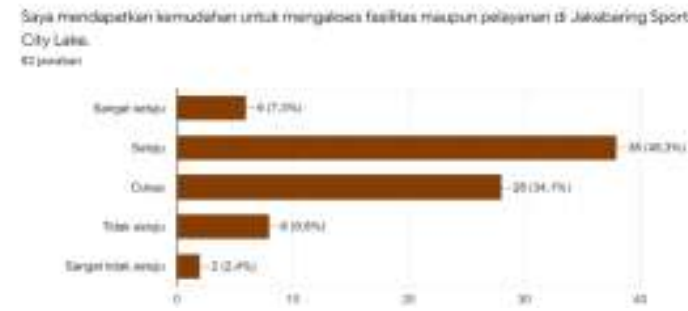

Figure 12 Respondents' preferences for the ease of accessing Jakabaring destination facilities and services

Source: Processed by the research team (2021)

In terms of ease of accessing facilities and services, 48.3 percent of respondents agreed. 7.3 percent stated strongly agree. While 34.1 percent said it was enough.

\section{CONCLUSION AND SUGGESTION 5.1 Conclusion}

Based on the results of the research above, the conclusions that can be drawn from this research are as follows:

\subsubsection{Context Evaluation}

Based on the results of field observations, it was found that the initial operational data of Jakabaring Lake as a sport tourism-based tourism destination was managed by PT. Jakabaring Sport City (PT JSC) was founded based on the vision of the Governor of South Sumatra Province to create a modern sports area of international standard with "smart" and "green" characters. Regarding Article 331 of Law Number 23 of 2014 concerning Regional Government, the South Sumatra Provincial Government then formed a Regional Owned Enterprise which aims to obtain profits or profits based on the feasibility of the business field 
to be formed by issuing the South Sumatra Province Regional Regulation Number 8 of 2017 dated June 12, 2017 concerning the Establishment of a Regional Owned Company Limited Liability Company Jakabaring Sport City with operational implementation after the issuance of the Deed of Establishment of a Limited Liability Company PT Jakabaring Sport City Number 72 dated November 28, 2017 stipulates the establishment of a Regional Owned Company Limited Liability Company Jakabaring Sport City to manage regional assets owned by the South Sumatra Provincial Government.

The 6 missions carried out are organizing local, national and international sports and sports events, holding national and international exhibitions, providing facilities to support culinary tourism programs by making domestic and international culinary counters, providing family recreation facilities, providing a place for MSMEs to improve the local economy, digitize energy-efficient facilities and utilities and manage waste in an environmentally friendly manner.

While the conclusions related to the analysis of program needs carried out by the PT. Jakabaring Sport City team at Jakabaring Lake obtained data that promotional activities and building brand awareness and support from all stakeholders, maintenance and use of venues for multi-events, policies and management patterns that are more comprehensive and mutually exclusive. advantageous as well as the ease and access of providing facilities to support culinary tourism programs, facilities and facilities especially those related to safety and security, facilities and infrastructure needed as well as upgrading of related employees in supporting the digitization program of energy-efficient facilities and utilities.

The objectives of the program implementation carried out by the PT. Jakabaring Sport City team at Jakabaring Lake are promotion and building brand awareness, optimizing maintenance and use of venues for multi-events, aligning comprehensive management policies for culinary counters, setting high standards with safety and security. for family recreation as well as HR upgrading for digitization and energy saving.

\subsubsection{Input Evaluation}

The conclusion obtained from the input evaluation aspect is that there are 5 important units in the management of Jakabaring Lake carried out by the PT. Jakabaring Sport City team, these units are the main director, secretary, operational manager, marketing manager and finance and HR manager with their respective duties and authorities. However, those who specifically handled the venue development were not found, considering that practically no sporting event has been held in the Jakabaring lake area since the 2018 Asian games. The existing infrastructure is quite complete, based on the data it was found that there are at least 3 important aspects of infrastructure that are adequate, among others, economic infrastructure, social infrastructure and tourism infrastructure. Meanwhile, the facilities are also quite complete where there are basic tourism facilities such as travel agents, tour operators, tourist transportation companies, hotels, restaurants, restaurants, tourist attractions which are sufficient to make Jakabaring Lake a tourist destination. Conclusions from the aspect of funding or budgeting can be concluded with the statement that it is not sufficient to manage the entire complex area. However, there is a policy of managing the area into 2 areas, namely areas that produce and less productive areas. This policy is expected to provide a solution to the shortage of operational costs that have been exacerbated by the COVID-19 pandemic for the past 2 years.

\subsubsection{Process Evaluation}

Based on the data obtained by the research team, it can be concluded that tourist activities carried out in the Jakabaring Lake area include sightseeing, water sports such as canoeing, dragon boats, then other activities such as jogging, leisurely walks, and fun activities such as banana boating. Meanwhile, other activities of informal business managers in the Jakabaring Lake area are the business of renting game equipment, selling merchandise such as snacks, mineral water, and renting game equipment such as bicycles and several other things.

In the aspect of evaluating the results of employee services, survey data obtained that respondents stated that the employees on duty at Jakabaring Lake had a good appearance. A total of $46.3 \%$ of respondents agree with this statement. Meanwhile, in terms of the accuracy of the information provided by PT.JSC employees, $43.9 \%$ of respondents answered agree and $40.2 \%$ answered 
enough. Only 3.7 percent answered strongly agree while others answered disagree. Other data obtained is that as many as 54.9 percent of respondents said that employees on duty at Jakabaring Lake provide courteous service, while the majority of respondents agree that employees show concern and empathy. Only 3.7 percent strongly disagree.

\subsubsection{Product Evaluation}

The conclusion of the level of satisfaction is that by looking at the comparison of the results of the tourist survey of admission prices with the experience gained in the Jakabaring lake area, the majority agree that employees show concern and empathy. Another survey, namely respondents stated that the service of employees who served at Jakabaring Lake had met their expectations. From the aspect that Jakabaring Lake facilities are quite good and respondents stated that Jakabaring Lake meets what is expected by tourists compared to other places, while in terms of ease of accessing facilities and services, the majority stated strongly agree. But those who say enough are also not small.

\subsection{Suggestions}

\subsubsection{Operational}

The need to follow up on the program needs needed for the management of Jakabaring Lake as a tourist destination based on sports tourism. The intended program is promotion and building brand awareness and increasing support from all stakeholders, maintenance and use of venues for multi-events, policies, and management patterns that are more comprehensive and easy to access. by providing facilities to support sports tourism programs, facilities and facilities are directed to prioritize safety and security factors, and employee upgrading is required with comprehensive training to support the digitization program of energyefficient facilities and utilities.

\subsubsection{Research}

Based on the data described, it is suggested that further research can be explored and focused on how the planning is carried out and how the program implementation is implemented and run by PT. Jakabaring Sport City in the Jakabaring Lake area. It is hoped that further research can explore other aspects that are part of this CIPP evaluation to be more comprehensive.

\section{AUTHOR'S CONTRIBUTIONS}

Wisanggeni Agus Priyanto: Performed research, lead author, co analyzed data. Muhammad Iqbal Djohan: Corresponding authors, analyzed data, co-author. Daniel Sihombing: Coauthors, research site survey.

\section{ACKNOWLEDGMENTS}

Special thanks to PT. Jakabaring Sport City management, all the employees of Jakabaring Lake and participants in the research location

\section{REFERENCE}

[1] Baggio, R., Scott, N., Cooper, C. (2010 b): Network science: A review focused on tourism. Annals of Tourism Research, 37(3): 802-827.

[2] Basiya, R., dan Rozak, H. A., 2012, Kualitas Daya Tarik Wisata, Kepuasan Dan Niat Kunjungan Kembali Wisatawan Mancanegara Di Jawa Tengah, Jurnal Ilmiah Dinamika Kepariwisataan Vol. XI No. 2, Oktober, Hlm. 1-12

[3] Bieger, T. (1998). Reengineering destination marketing. Tourism Review, 53(3): 4-17.

[4] Bordas, E. (1994). Competitiveness of tourist destinations in long distance market. Tourism Review, 49(3): 3-9.

[5] Bornhorst, T., Ritchie, J. B. R., Sheehan, L. (2010): Determinants of tourism success for DMOs \& destinations: An empirical examination of stakeholders' perspectives. Tourism Management, 31(5): 572-589

[6] Buhalis, D. (2000): Marketing the competitive destination of the future. Tourism Management, 21(1): 97-116.

[7] Burkart, A. J., Medlik, S. (1974): Tourism. Past, present and future. London, Heinemann

[8] Butler, R. (1980). The Concept of a Tourist Area of Life Cycle of Evolution: Implications for Management of Resource. Canadian Geographer Volume 19 No.1 , 512. Butler, R. (2011). Tourism Area Life Cycle. Oxford: Goodfellow Publisher.

[9] Capone, F., Boix, R. (2003): Sources of competitiveness in tourist local systems: An application to Italy. Proceedings of 45th Congress of the European Regional Science 
Association, Amsterdam, 23-27.10.2003: 23-27.

[10] Cooper, Fketcher, J., Gilbert, D., \& Wanhill, S. (1995). Tourism, Principles and Prantice. London: Longman.

[11] Cooper, C., Fletcher, J., Gilbert, D., \& Wanhill, S. (1996). Tourism Principle \& Practice. London: Longman Group Limited.

[12] D'angella F., Sainaghi R. (2004): Building competitive advantage of district firms: the role of the network and the company. In: Keller P., Bieger,

[13] Flagestad, A. (2002): Strategic success and organisational structure in winter sports destinations. A multiple stakeholder approach to measuring organizational performance in Scandinavian and Swiss case studies. Östersund, ETOUR.

[14] Follet , Marry Parker, 1997. Manajemen Dalam Organisasi, Kencana, JakartaWidoyoko (2011)

[15] Framke, W. (2001): The 'destination': A problematic concept. Paper presented at $10^{\text {th }}$ Nordic Tourism Research Conference, Vasa 19-20.10.2001

[16] Gammon, S., \& Robinson, T. (2003). Sport and Tourism: A Conceptual Framework. Journal of Sport \& Tourism, 8(1), 21-26. doi:10.1080/14775080306236

[17] Goeldner, C. R., Ritchie, J. R. B. (2003): Tourism: principles, practices, philosophies. Hoboken, Willey.

[18] Gonçalves, V. F. C., Águas, P. M. R. (1997): The concept of life cycle: An application to the tourism product. Journal of Travel Research 35(4): 12-21

[19] Hu, Y., Ritchie, J. B. (1993): Measuring destination attractiveness: A contextual approach. Journal of Travel Research, 32(2): 25-34.

[20] Izadi, R., Saberi, H.(2015): Comparative study of selecting tourist destinations abroad: A case study of Antalya and Dubai cities. Journal of Sustainable Development, 8(9): 147-156.

[21] Karo Karo, P., \& Rahman, A. (2020). Analisis Pengaruh Experiential Marketing Terhadap Tingkat Kepuasan Peserta Sports Event Jakabaring Wonderful Run Palembang. PUSAKA (Journal of Tourism,
Hospitality, Travel and Business Event), 2(2), $127-135$. https://doi.org/10.33649/pusaka.v2i2.32

[22] Kim, Aise Kyoungjin And Brown, Graham (2012) "Understanding the relationships between perceived travel experiences, overall satisfaction, and destination loyalty" doi: $10.1080 / 13032917.2012 .696272$

[23] Koestantia, T., Nuryanti, W., Suwarno, N., Prayitno, B., Femina, D. (2014): The distribution pattern of creative industries and the spatial system of tourist destinations in Indonesia: The case of Bandung. International Journal of Architecture and Design, 25(2): 1140-1148.

[24] LEIPER, N. (2004): Tourism management (3rd ed.). Frenchs Forest, Pearson Education, Australia

[25] Mario Barreto dan Ketut Giantari, (2015)."Strategi Pengembangan Objek Wisata Air Panas Di Desa Marobo, Kabupaten Bobonaro Timor Leste", E-Jurnal Ekonomi dan Bisnis Universitas Udayana Bali, Vol.4:11.2015.

[26] Mariutti, F. G., Giraldi, J. D. M. E., Crescitelli, E. (2013): The image of Brazil as a tourism destination: an exploratory study of the American market. International Journal of Business Administration, 4(1): 13-22.

[27] Murphy, P. (1985): Tourism. A community approach. London, Routledge.

[28] Musselman. Vernon A., John Jackson (1990). Ekonomi Perusahaan. Edisi 10. Jilid 2. Intermedia. Jakarta

[29] Parasuraman, A., Valarie A. Zeithaml, and Leonard L. Berry. (1990). Delivering Quality Service : Balancing Customer Perceptions and Expectations. New York : THE TREE PRESS.

[30] Spillane J.J,1987,Pariwisata Indonesia Sejarah dan Prospeknya, Yogyakarta, Kanisius

[31] Pechlaner H. (1999): The competitiveness of Alpine destinations between market pressure and problems of adoption. Tourism, 47(4): 332-343.

[32] Purnama. 2006. Manajemen Kualitas Perspektif Global edisi pertama cetakan pertama. Yogyakarta. Fakultas Ekonomi Universitas Islam Indonesia 